\title{
ANACHRONISTIC JUDICIAL APPROACHES TO DISABILITY BENEFITS LAW
}

\author{
Dr. Amir A. Majid
}

Based on the research carried out on behalf of the Secretary of State for Social Security in 1984 by the Office of Census and Public Surveys, the Government published a White Paper, The Way Ahead - Benefits for Disabled People. ${ }^{1}$ The new regime gave disabled people under 65 additional entitlement to lower mobility and care components of the Disability Living Allowance [D.L.A.] less serious mobility and care needs were recognised for which disabled persons could not claim any cash benefits before. The new legislation also granted a claimant the competence to self-assess unlike in the past whereby the disability-related benefits were assessable with reference to medical evidence. All three benefits (as well as the two levels of Attendance Allowance [A.A.]) are not means tested and do not attract any taxation.

This article is concerned with the developments in the criteria of A.A. and D.L.A., as affected by recent case law. ${ }^{2}$ It will show that judges have not kept pace with modern changes. First, they have not modified their approaches, often to the serious detriment of disabled claimants, in line with the substantially more generous provision of disability benefits. Secondly, they have failed to faithfully implement the will of the Parliament, mirroring the improvement in the attitude of society towards disabled people, to enable them to play a full role in society and give them the means to lead an independent life in the community. The article will highlight some of the restrictive judicial

\footnotetext{
- Barrister (Cloisters Chambers), Reader in Law (London Guildhall University). The author expresses his warm thanks to his senior friend, Professor Anthony Bradley, for perusing the manuscript and giving generously the benefit of his wisdom to improve this article.

1 Other than the Attendance Allowance (A.A.) for people over 65, Disability Working Allowance.(D.W.A.) and Disability Living Allowance (D.L.A.) were introduced for persons under 65 but normally over 5 . The White Paper hailed the introduction of these benefits to be "a fundamental change" in the system; see The Way Ahead-Benefits for Disabled People Cm.917, (H.M.S.O., 1990).

2 Particularly Cockburn v. Chief Adjudication Officer and Another; and Secretary of State for Social Security v. Fairey, also known as Halliday, a single judgment for the two cases was issued on $21^{\text {st }}$ May, 1997 - [1997] 3 All E.R. 844. (Also reported: [1997] 1 W.L.R. 799.) Hereinafter referred to as "the Cockburn case" and "the Fairey case" respectively.
} 


\section{THE DENNING LAW JOURNAL}

interpretations given to various statutory phrases which, it is argued, were not inexorable in light of the changes in the current animus legis.

The D.L.A. is divided into two main components, "Mobility" and "Care." The former component (bifurcated into higher and lower levels) deals with transport and mobility problems and is not the subject of discussion in this article. The latter component deals with the "care needs" of a disabled person and, depending on the severity of needs, is divisible into three levels, "highest," "middle" and "lowest." The major differences are that A.A. is only available at the "highest" and "middle" levels and the "lowest" level is not available to claimants who were not receiving it and claimed the benefit when they were over 65; further the qualifying period for D.L.A. is three months and this period for the A.A. is six months. Other than these differences, the criteria and procedures for the grant of A.A. are mutatis mutandis similar to those applicable to the D.L.A. As in section 64 in respect of the A.A., the criteria for entitlement to D.L.A. are governed by section 72 of the Social Security (Contribution and Benefits) Act $1992 .^{3}$

The Fairey case, decided on $21^{\text {st }}$ May, 1997, focuses on the care component of the D.L.A. because the claimant was under 65 . Since Mrs. Cockburn was a claimant over 65 , her case decided on the same day related to A.A.. Bearing in mind these differences, in the discussion below the arguments concerning "D.L.A." cover both benefits.

As it was reiterated in the House of Lords, in the Fairey case, at the earlier stages of litigation the Department of Social Security [D.S.S.] asserted that "social activities" such as going to cinema or theatre, or travelling to and from and visiting museums etc. were not "essential." The Department submitted that it could not be said that attention in respect of these needs was "reasonably required." This view was rejected by Mr. Commissioner Sanders who was persuaded otherwise and, accordingly, he allowed Miss Fairey's appeal on $14^{\text {th }}$ October, 1994. He said:

${ }^{3}$ For further information viz the applicable criteria and procedures of grant, see J.Paterson, Disability Rights Handbook (Disability Alliance, $25^{\text {th }}$ ed., 2000-2001) at pp.124-148;

C. George et al, Welfare Benefits Handbook (C.P.A.G., $2^{\text {nd }}$ ed., 2000-2001) at pp.157-196; Ogus, Barendt \& Wikeley's The Law of Social Security (Butterworths, $4^{\text {th }}$ ed., 1995); for some basic information and useful references of detailed sources see Mike Hurdiss, "The Who, When and How of DLA" Disability Now 18 (SCOPE, August 2000).

4 The House of Lords, as the courts below, was invited to accept the Department's view that Miss Fairey had sufficient social life because she could communicate with her mother who knew sign language and with some other individuals who could communicate in that manner. Any further desire for socialisation was not "reasonably" required 


\section{DISABILITY BENEFITS LAW}

"I take the view following, as it seems to me, the approach in the last few cases to which I have referred that it is right to include in the aggregate of attention that is reasonably required such attention as may enable the claimant to carry out a reasonable level of social activity. Deriving strength from the decision of the House of Lords in the Mallinson case, the majority of the Court of Appeal (Glidewell LJ and Swinton Thomas LJ) definitively dismissed the appeal and expressly approved the test of the Commissioner for 'reasonably required attention."

\section{SALIENT POINTS OF THE FAIREY CASE}

In the past, over-technical literal construction of statutory wording of relevant provisions has led to absurd results. Rather refreshingly, Lord Slynn takes a purposive and justice-oriented approach and thereby avoids falling into the pit of "cold logic." In the House of Lords, Lord Slynn, who delivered the leading opinion, observes:

"It may well be that, on a strict analysis and in logic, attention cannot be in connection with a bodily function which does not function and never has functioned since birth, but it seems to me impossible to attribute to Parliament the intention to exclude from the section attention given to a person whose bodily functions (sight or hearing) are wholly impaired and to limit it to someone whose bodily functions are partially impaired. If an over-fine analysis of each of the words in the section leads to such an absurd result it is necessary, as Lord Bridge of Harwich stressed in Woodling, ${ }^{6}$ to look at the language of the section as a whole to find the intention."?

Lord Slynn enunciated that the correct test in the D.L.A. cases was to take into account "attention" which is reasonably required "to enable the severely disabled person as far as reasonably possible to live a normal life.",8

\footnotetext{
5 In fact this test was clearly established in $R$. v. Secretary of State for Social Services ex parte Connolly [1986]. 1 W.L.R. 421.

${ }^{6}$ In Re Woodling [1984] 1 W.L.R. 348, at 352; [1984] 1 All E.R. 593 at 596.

7 Supran. 2 at $859 \mathrm{f}-\mathrm{g}$.

8 Ibid at $860 \mathrm{e}$.
} 


\section{THE DENNING LAW JOURNAL}

"He is not to be confined to doing only the things which totally deaf or blind people can do and provided with only such attention as keeps him alive in such a community."

\section{Lord Slynn stated that:}

"the yardstick of a 'normal life' is important; it is a better approach than adopting the test as to whether something is 'essential' or 'desirable.' Social life in the sense of mixing with others, taking part in activities with others, undertaking recreation and cultural activities can be part of normal life. It is not in any way unreasonable that the severely disabled person should wish to be involved in them despite his disability." 10

\section{SALIENT POINTS OF THE COCKBURN CASE}

Mrs. Cockburn's appeal was dismissed by a majority of four to one (Lord Slynn dissenting). In his leading judgment in respect of the Cockburn case, Lord Hope of Craighead endorsed Mr. Commissioner Monroe's definition of "bodily functions" in Decision CA/60/74, as approved by Lord Bridge of Harwich in the Woodling case; also emphatically adopted by Lord Justice Dunn in Packer's case. ${ }^{11}$ Namely those functions which "the fit man normally performs for himself." Are "washing," "cleaning," "sweeping" or "dusting" not the functions which a fit man normally performs for himself?

Perpetuating the myth introduced by Packer's case in 1981, Lord Bridge inserts the test of "intimacy," "physical contact" and "personal attendance" as being essential elements in giving "attention" for it to merit recognition for the award of D.L.A. or A.A. ${ }^{12}$ Without realising that it does injustice to many disabled claimants living alone, Lord Hope takes this statutory construction as given - as if this interpretation is something "compelled" by the language of the 1992 Act or its predecessor, the Social Security Act 1975. It is most respectfully submitted that this restrictive interpretation should be abandoned as a yardstick

\footnotetext{
9 Ibid.

${ }^{10}$ Ibid at $860 \mathrm{f}-\mathrm{g}$. Professor. Wikeley, referring to the Department's attempt to confine the need for attention to "essential," as opposed to "desirable" communication, said that it "seems at best outdated and at worst grossly insensitive to the position of those with hearing loss." See, infra n. 14 at p.556.

11 . v. National Insurance Commissioners ex parte Secretary of State for Social Services [1981] I W.L.R. 1017, generally known as Packer's case. For discussion on this case, see Ogus, Barendt \& Wikeley, supra n.3 at pp.200-202

12 Supra n.6.
} 
because it leads to ignoring some proper incidences requiring "attention" and culminates in neglect of some genuine "care needs" of a claimant - provision of relief for "care needs," of course, is the principal object of the Act in question.

In his opinion in the Cockburn case Lord Hope of Craighead finds that Mrs. Cockburn's care needs are not sufficient because they do not "satisfy the terms of the statute in the light of the policy which Lord Bridge of Harwich has described." Lord Bridge (the author stresses the fact that this was in 1984) had detailed the "policy" as follows:

"First it is clear that the policy underlying section 35 of the Act stops short of providing Attendance Allowance for all who are incapable of looking after themselves without some outside help even if that help is frequently required. ... Again it seems a reasonable inference that the policy of the enactment was to provide a financial incentive to encourage families or friends to undertake the difficult and sometimes distasteful task of caring within the home for those who are so severely disabled that they must otherwise become a charge on some public institution."

Lord Hope does not appear to have been acquainted with the modern reality (and a mammoth reality) that there is a much more illuminated and healthy approach by the Government towards normalising the lives of disabled people. He might have been misled viz this approach by Lord Justice Hobhouse's statement in the Court of Appeal in the Fairey case. After setting out the above dictum of Lord Bridge of 1984, Lord Justice Hobhouse opines: "I consider that the same overall policy guides the relevant provision in the 1992 Act."15

When Lord Bridge was describing the policy of the statute in 1984 , the animus legis behind the 1975 Act (which his Lordship was considering) had not accorded with the proper needs and aspirations of disabled people. Moreover, his Lordship does not give any impression that he is expounding the policy in a balanced way. The author is inspired to make this comment by his Lordship's view of the policy of the Act that it excludes disabled claimants even if they require help "frequently." This kind of disabled claimant is, indeed, expressly

13 Supran.2 at $869 \mathrm{f}$.

14 Supra n. 6 at 352 d-e. A disability benefit (Attendance Allowance) was first introduced by s. 4(2) of National Insurance (Old Persons and Widows Pensions and Attendance Allowance)

Act 1970. For historical evolution and enhancement in the disability benefits, it is argued, reflecting the more enlightened attitudes of society towards disabled people, see N.Wikeley, "Cases: Benefits, Bodily Functions and Living with Disability" (1998) 61 M.L.R. 551 at pp. 551-552.

Fairey Case, Court of Appeal Judgment Transcript, P. 23b 


\section{THE DENNING LAW JOURNAL}

and specifically envisaged by the Act to be covered when one notes that section 35(a)(i) of the Social Security Act 1975, the policy of which Lord Bridge was considering, states that a person will be entitled to the benefit in question if he/she required "frequent attention throughout the day in connection with his bodily functions."

In consequence of a sustained campaign of disabled activists, the 1992 legislation had imported a progressive approach in the benefits system. That the description of the "policy" by Lord Bridge is erroneous is also clear from the fact that only a disabled claimant is the lawful recipient of the D.L.A. and "families or friends" are not even entitled to know whether a disabled person is receiving any D.L.A..

It is submitted that the introduction of the "lowest" level of D.L.A. care component, based on the "cooking test" for people over sixteen was not entirely a de novo concept but a conscious recognition by Parliament, highlighted by disability campaigners, that the courts in the cases of Packer (1981) and Woodling (1984) had taken an over-rigid approach in excluding "cooking." Further, the benefits regime was expanded by providing for mobility needs of scores of thousands more disabled people by the introduction of the lower component of the mobility element of D.L.A..

The landmark of distinct positive change in the social policy aimed at bettering the lives of disabled people was February 1991 when the third reading of the modern legislation was taking place in parliament. Sadly, this reality does not feature in the cases of Mallinson and Cockburn and Fairey. The judges remain fidel to the dicta of 1981 in Packer's case and of 1984 in the Woodling case, without noticing the outmodedness of some aspects of these cases.

The attitudes of the society and Government have been going through a metamorphosis since the Social Security Act 1975, an Act which was probably a progressive measure at that time. Taking the example of February 1991 when the amplification of the provision for disabled claimants was being considered, the Government, according to the Minister for Disabled People, saw this to be "an opportunity to enable disabled people to enjoy a quality of life that has been denied to their predecessors and many of them." ${ }^{\prime 6}$ The Minister further said that:

16 House of Commons, Official Reports, Parliamentary Debates, Hansard, $7^{\text {th }}$ February, 1991, Vol. 185, Issue 51, col. 440 (hereinafter the Hansard) 


\section{DISABILITY BENEFITS LAW}

"the Bill will introduce two important benefits. The Disability

Living Allowance will combine and extend the impact of

Attendance and Mobility Allowances in an effective way."17

Repeating in the third reading what he had said earlier at the committee stage, Mr. Scott said in February, 1991:

"The pattern of benefits that we have introduced is but a part of what all Honourable Members concerned about the subject want

- a series of measures that improve the lives of disabled people." 18

He highlighted the Government's desire to improve "accessibility to leisure facilities and to the other matters that the rest of us are able, for the time being at least, to take for granted."19

\section{CONUNDRIES OF STATUTORY PHRASES}

The trap into which the cold logic of intellect dropped the judiciary is the construction of the quaint phrases, the worst of them being the statutory terms "bodily functions" and "attention." In the Woodling case, for instance, Lord Bridge opined that the phrase "bodily functions" is "a restricted and precise one, narrower than for example "bodily needs." ${ }^{20}$ His Lordship then proceeded to use this formulation to justify exclusion of cooking from "bodily functions." A purposive glance at the provision could readily lead to the inclusion of "cooking" in the care needs of a disabled person, e.g. a claimant has no hands (clearly an impairment depriving him of the ability to accomplish several bodily functions) and included in his care needs is that he cannot "cook." Is it so unreasonable a "care need" that it should not be taken into account in ascertaining his statutory entitlement to financial help from the State?

\footnotetext{
17 Ibid at col. 493. The remarkable fact is that this kind of progressive measures were envisaged by the pioneer legislators of the award of disability benefits. For instance, the Secretary of State, Mr. David Ennals, when addressing the Committee said that not for a moment did he anticipate that the provisions which he expected the 1970 Bill to contain "to remain unchanged for many years to come. That would represent a failure by the Government and society to represent the needs that we are starting to meet in this Clause." Standing Committee F, col. $548,10^{\text {th }}$ March, 1970.

18 Supra n. 16 at col. 493

19 Ibid.

20 Supra n.6.
} 


\title{
THE DENNING LAW JOURNAL
}

To uncover the roots of the current anachronistic judicial approaches towards disability benefits, re-visiting the circumstances of Packer's case may be very revealing.

In Packer's case, upholding the Commissioner's decision, Mr. Justice Forbes, had taken an even more progressive approach in the High Court than the Commissioner against whose decision the Secretary of State was appealing. Mr. Justice Forbes said:

\begin{abstract}
"Cooking is an activity which consists of the application of a number of bodily functions to a particular task and if a disabled person cannot perform the requisite bodily functions himself then someone who performs them on his behalf is rendering attention in connection with those bodily functions and, accordingly, the Delegated Medical Practitioner is wrong to exclude from his consideration the fact that the disabled person needed to be cooked for.",21
\end{abstract}

Indeed, even in 1981 (certainly and manifestly in the subsequent years) those working in the social security field, many Commissioners and advisers to the claimants, had no doubt that the necessity that a disabled person who could not cook for himself needed "to be cooked for" to meet the most important function of all "bodily functions" i.e. "eating" could rationally count towards the "attention" required for entitlement to an Attendance Allowance. This reasoning had produced the cumulative weight on the government to start drafting in 1990, pass in 1991 and enforce new legislation introducing, inter alia, the lowest care component of D.L.A. specifically granting benefit to those who could not cook for themselves.

The author finds the conclusion of the Court of Appeal in Packer's case that "cooking" was too remote from the "bodily function" of "eating" incomprehensible when he sees that the Court of Appeal had before it (and records it in its judgment) the self-evidently commendable reasoning of three National Insurance Commissioners that cooking was "attention" and that the:

"personal service of an active kind involving cooking is
immediately and not remotely connected with the bodily
function of eating. Indeed, preparing food for an invalid cannot

${ }^{21}$ Supra $n .11$ at 1020 


\title{
DISABILITY BENEFITS LAW
}

reasonably be regarded as having any purpose other than satisfying the bodily function of eating." 22

In the Cockburn case, Lord Goff of Chieveley stated:

\begin{abstract}
"Obviously, the requirement of presence has not to be applied too strictly ... but it marks a characteristic of the attention which is required and taking away washing to be laundered elsewhere cannot, in my opinion, sensibly be regarded as constituting part of such attention. But, though performance of the relevant activity away from the applicant excludes it from the ambit of the section, the mere fact that it is performed in the applicant's presence is not of itself a qualification. ${ }^{, 23}$
\end{abstract}

${ }^{22}$ Ibid at 1024 . Out of the four decisions of four different Commissioners before the Court of Appeal, only one of them, Commissioner Monroe, had taken an excessively restrictive approach (because he appears to keep the meaning of "bodily functions" within the narrow penumbra of meanings such as eliminating waste products). To make conspicuous the anomalous choice of reasoning by the Packer Court of Appeal, one of the other three Commissioners, Sir Rawden Temple Q.C.'s analysis is worth repeating:

"The logical result of confining attention to actual physical assistance given to a disabled person is, for example, that he would be receiving attention of the required character whilst being bathed but not whilst the bath was being prepared for him, and be receiving attention when his food was being cut up to enable him to eat it, but not whilst it was being prepared to enable it to become edible. Such fine distinctions wholly unintelligible, I would suppose, to those for whose benefit the legislation exists and which fragment the course of personal services given to the severely disabled in regard to their bodily functions, do not attract me. In my opinion 'attention ... in connection with bodily functions' should be broadly interpreted, so as to include not only any physical assistance ultimately given to enable a disabled person to eat (or drink) but also to include the necessary steps taken by the attendant to prepare the food or drink which is to be consumed with or without later physical assistance to do so. For myself, I do not doubt that a disabled person waiting for food or drink to be prepared, if asked whether he was being attended to, or receiving attention, would answer that he was, and such an answer to my mind would accord both with commonsense and with the fact. I do not believe that the Parliament intended that the disabled person, waiting whilst an attendant prepared a meal or special diet which he was unable to do for himself because of his disability, should be held not to be receiving attention in connection with his bodily function." ibid; also Decision CA2/79, $27^{\text {th }}$ August, 1979. 


\section{THE DENNING LAW JOURNAL}

In his dissenting opinion, Lord Slynn regarded it to be an incorrect approach to identify a matter to be a "household chore" (the view which was taken by Lord Denning and Lord Justice Dunn in Packer's case and Lady Justice ButlerSloss adopted it in the Cockburn case in the Court of Appeal) and then exclude it from the "attention" recognised by the 1992 Act. Instead, "it must specifically be asked whether the particular washing is required in connection with bodily functions. ${ }^{24}$ Referring to a Commissioner's Decision, RA1/91, his Lordship indicated circumstances in which "washing" may be linked to the failure of a "bodily function" thus constituting "attention" falling within the ambit of the Act.

Lord Slynn discouraged the over-rigid approach in construing the statutory expressions in the field of Social Security Law. He said, "I do not think that it helps to adopt particular categories which cannot ever be capable of constituting attention." 25 Accepting that attention "must have the active, close, caring personal qualities," Lord Slynn does not think that "attention necessarily involves physical contact." His Lordship rejected the view that there has always to be personal attendance on the claimant to constitute "attention" and said that:
"it would be quite absurd to say that to prepare a sponge in a basin in the bedroom qualifies but that the same prepared in a bathroom on the same or on a different floor does not. ${ }^{.26}$

Lord Mustill's weightiest reason for Mrs. Cockburn's appeal appears to be his Lordship's insistence on the condition that for meriting inclusion in the attention required by the Act the helper must be "in attendance on the applicant" and be present with him. ${ }^{27}$ To justify dismissal of Mrs. Cockburn's appeal, Lord Mustill says, "I found it hard to see how one visit a week could be 'frequent attendance throughout the day." 28 His Lordship, however, recognises that if a person comes into the home to strip the bed and provide other help to the disabled person and then stays in the home "to rinse the linen and hang it up to dry" that falls within the section. ${ }^{29}$

Most regrettably, his Lordship was not made aware of the fact that since 1992 when the new legislation was brought into force, if not before, the help (attention or supervision) to be taken into account by the decision makers is the

\footnotetext{
${ }^{24}$ Ibid at $863 \mathrm{~b}$.

25 Ibid at $863 \mathrm{j}-864 \mathrm{a}$.

26 Ibid at $864 \mathrm{~b}-\mathrm{d}$.

27 Ibid at $850 \mathrm{~d}$.

28 Ibid at $849 \mathrm{~b}$

${ }^{29}$ Ibid at 849 j
} 
help the disabled person reasonably "needs" and not the help he "actually receives." Thus, there will be many occasions when a claimant will need help but there will be nobody to help him. At times, a helper can visit the claimant less frequently than he would need. If benefits are allocated with reference to what actual help is being received by a claimant, then resourceful disabled persons capable of arranging help for their genuine but minor needs can obtain benefits and disabled persons with more and major care needs may be neglected because they were not receiving help frequently. It will be the most anomalous situation whereby the system fails to help those who are waiting for a benefit to come into their hands to buy in care services for their serious needs.

It may here be indicated that both judges and advocates presenting cases before them, in some instances, have displayed imperfect command of the overgrown minutiae ridden rules of Social Security Law. In Packer's case, for example, Lord Denning, adopting Lord Justice O'Connor's view in that case, said:

"It would appear that the daughter gave up her work in order to be at home to look after her mother. She would therefore be entitled to receive an Invalid Care Allowance under s.37 of the Act, payable to her and not to her mother. In that way she will I hope be well treated and everything will be fair all around."330

Lord Denning was incorrect in making the preceding statement. The courts in England depend on advocates to inform them of intricate details of a specific field of law. Here, the advocates dismally failed in their duty. The correct law was adumbrated before the court three years afterwards in the Woodling case, and the House of Lords emphatically indicated that the Court of Appeal in Packer's case was wrong in saying that the daughter was so entitled. One may even call it a blunder because by refusing the grant of Attendance Allowance to Mrs. Packer the Court of Appeal had in fact expunged the very requirement which was the condition precedent to obtaining an Invalid Care Allowance by anybody looking after her.

Totally indistinct, rather than transparently guiding, approaches of various judges are visible in a number of cases. The most glaring example of this can be seen by surveying the events until the moment the Mallinson appeal reached the House of Lords. The Delegated Medical Practitioner (the original decision

30 Supran. 11 at 1022 . 
maker), the Commissioner and the three Lord Justices of Appeal managed to produce a concoction of about five different strands of reasoning. ${ }^{31}$

This author clearly believes that, without any clear statutory strictures, some of the restrictions imposed by the courts (to the detriment of claimants who tend to be mostly poor) are unjustified. "Washing," "cleaning," "sweeping" and "dusting," it is most respectfully submitted, are wrongly excluded from the "care needs." The decision in this particular respect in Packer's case is an anachronism. As the previous courts, Lady Justice Butler-Sloss in the Cockburn case in the Court of Appeal took these exclusions to be justified ex cathedra. ${ }^{32}$

As already discussed, the Court of Appeal in Packer's case, rejecting (it is most respectfully submitted) the fair and commonsensical approaches of three Commissioners, adopted the overly strict approach of Commissioner, Mr. J. G. Monroe, in his decision CA60/74 of $23^{\text {rd }}$ October 1974. This was an earlier decision than the one given by Chief Commissioner, Sir Rawden Temple Q.C., on $27^{\text {th }}$ August 1979, (Decision CA2/79, discussed above and available for consideration by the Packer Court.). Sir Rawden's decision advocated a fair approach to include cooking in the care needs. In the Woodling case, Lord Bridge, endorsing this facet of Packer's case, made clear that the section should be construed in the "restrictive sense" rather than the "broad sense" and, consolidating this unfair point, his Lordship added that "the restricted construction is the correct one.,"33

In the Fairey case in the Court of Appeal, Lord Justice Hobhouse found himself totally convinced by the strict approach taken by the Court of Appeal in Packer's case and the House of Lords in the Woodling case. He, in fact, said that Lord Woolf could not take the approach he took in the Mallinson case in 1994 because he was bound by Lord Bridge's dictum in the Woodling case of 1984 - an over-zealous application of the doctrine of precedent. ${ }^{34}$ What is

31 "Attendance Allowance, Disability Living Allowance and Blindness" SCOLAG J. 152-154 (October/November 1994). If one looks at the Cockburn and Fairey judgments, one confronts the glaring incongruity that Miss Fairey (a young, healthy and employed woman with hearing impairment) is found to be entitled to the D.L.A. but a 71-year-old woman with severe arthritis and incontinence did not merit the benefit - "In a sense the help required by the claimant in Cockburn was more obviously within the policy underlying the benefits." Robertson and Thomas, "Social Security: Recent Developments" Legal Action 16 at 21 (August 1997) Commissioner Howell Q.C. has drawn the attention of Parliament to this controversy because he is doubtful "whether the present manifest imbalances between claimants with different form of disability are now capable of remedy by judicial interpretation." CDLA/11652/95, para. 12.

${ }^{32}$ Supra $\mathrm{n} .2$ at $867 \mathrm{c}$.

${ }^{33}$ Supran.6.

${ }^{34}$ Supran 2 at 858 e (where Lord Justice Hobhouse is quoted). 
substantively objectionable about Lord Justice Hobhouse's dissenting judgment in the Fairey case is that his Lordship appears to be oblivious of the substantial and, one may be justified in saying, radical changes since 1984 in social attitudes and parliamentary policy, leading to further enhanced provision being made for disabled persons.

In the Cockburn case, Lady Justice Butler-Sloss said:

"A line has to be drawn somewhere and it is clearly drawn in Packer's case (R. v. National Insurance Commissioners ex p. Secretary of State for Social Services [1981] 1 W.L.R. 1017) between cooking, shopping and, I would add, housework such as dusting, cleaning, sweeping and laundry on the one hand and, on the other, close personal attention such as helping in and out of bed, eating, drinking, bathing, washing hair, going to the lavatory. The latter, non-exhaustive list of duties, following the line of authority established over fifteen years, do fall within attention ... in connection with bodily functions. The former type of duties do not. To find otherwise would be not to recognise the restricted and precise meaning of the phrase 'bodily functions' nor the high degree of physical intimacy between the giver and receiver of attention required by Lord Bridge in In Re Woodling [1984] 1 W.L.R. 348. 35

In Packer's case Lord Justice Dunn after saying that "[a] line must be drawn somewhere" thought that "the work in the kitchen was outside the ambit of the statutory provision." $" 36$ This interpretation was not compelled by the statute or, it is respectfully submitted, dictated by the policy of the statute.

The expression "bodily functions" is not defined in the statute. A novice to the field of social security law may be forgiven for assuming that it means that the functions concerned were only of an intimate personal nature - taking in food or liquid or excreting waste products of the body. However, it covers much more than that. In Packer's case Lord Denning, M.R., stated:

"Bodily functions include breathing, hearing, seeing, eating, drinking, walking, sitting, sleeping, getting in or out of bed, dressing, undressing, eliminating waste products and the like, all

${ }^{35}$ Case Note III, J.of S.S. Law 4 at pp.163-164 (1996).

36 Supran.11 at 1027. 


\section{THE DENNING LAW JOURNAL}

of which an ordinary person, who is not suffering from any disability, does for himself."37

"Seeing" is clearly recognised as a "bodily function" in this long list of examples. Both courts and, consequently, those officials who are responsible for administering the benefits in the D.S.S. failed to give effect to this dictum in dealing with visually impaired claimants. Only in April 1994, the Mallinson judgment of the House of Lords made it clear that "seeing" was a bodily function. Even the Mallinson judgment in favour of visually impaired applicants was in danger of falling into disuse if the Fairey appeal had not reached the House of Lords.

In the Court of Appeal in the Fairey case, Lord Justice Hobhouse stated that he understood that "seeing" was not recognised by the majority of the House of Lords to be a "bodily function" in the Mallinson case. This view was forcefully expressed by his Lordship because he wished to give effect to "the narrowness of the bodily functions" ${ }^{238}$ and, if it had prevailed, it would have possibly rolled back the law to where it was before the Mallinson case. His Lordship's dissenting judgment could have been followed by a future Court of Appeal and, consequently, tens of thousands of visually impaired individuals could have been deprived of financial benefits which their needs amply justify.

Most fortunately for visually impaired claimants, the Fairey case reached the House of Lords and Lord Slynn rejected Lord Justice Hobhouse's view. According to Lord Slynn's analysis (not derogated from by any of the other Law Lords) Lord Woolf's opinion in the Mallinson case that "seeing" was a "bodily function" was concurred in by two other Law Lords and was, therefore, a majority view in that case. It may be reiterated that, since all other Law Lords approved Lord Slynn's analysis of the Mallinson judgment, the Fairey and Cockburn decision itself is a unanimous authority that "seeing" is a "bodily function."

Lord Justice Hobhouse made an extra-nice epistemological distinction between "disability" and "bodily function" and emphasised that the disability has to be in connection with the claimant's bodily functions. He says that the statutory words were not "in connection with her disability." 39

This distinction is unmeritorious since it does not accord to the legislative purpose and ignores care needs of scores of thousands of disabled claimants for whom Parliament has devised the system of these benefits.

${ }^{37}$ Ibid at $1022 \mathrm{~b}-\mathrm{c}$.

38 Supran.15 at 57.

39 Supra n.2 at $857 \mathrm{~h}-\mathrm{i}$. 
As compared with the total neglect of the dictum relating to "seeing" in Packer's case, (1981), for thirteen years until the Mallinson case, the exclusionary dictum viz the "domestic chores" such as cooking, washing, shopping and ironing (reducing or obviating entitlement) was duly and promptly seized upon not only by the administrators of the system but also by the judges in subsequent cases. ${ }^{40}$ No judge in recent years, other than Lord Slynn in the Fairey and Cockburn cases, felt motivated to indicate that this kind of indiscriminate neglect of care needs is not "compelled by the statute" and there may be cases where such needs can be taken into account validly.

The judges have expressed great sympathy with the unsuccessful claimants and have regretted the adverse effects of their negative decisions on their lives. It gives the impression that they are not fully in touch with the changing culture wherein more and more support is made available to disabled people. At times they have mentioned that they were precluded from being generous because they had to be fair to the public purse. Lord Mustill took up this theme in the Fairey and Cockburn cases thus:
"The courts must I believe bear in mind that the entire shape of social services legislation represents a strategy about the deployment of limited funds and that to overstrain one element of legislation in order to relieve someone whose case attracts sympathy will only divert resources from someone else whose case falls squarely within the intention of the scheme. ${ }^{, 41}$

The judges appear to be unaware of the plight of disabled persons in the United Kingdom. Many of them have to make a choice between keeping warm or buying sufficient food, in addition to facing the cost of travelling etc. Between 1979 and February 1991, whilst average earnings had arisen by 20 per cent, the benefits had increased only by 1 per cent. ${ }^{42}$ With the maximum positive impact

\footnotetext{
${ }^{40}$ Except for one or two judges, this statement applies to virtually all judges involved in the cases of Packer (1981), In Re Woodling (1984), Mallinson (1984, House of Lords; also the Court of Appeal stage), Cockburn (1995, Court of Appeal), Fairey (1995, Court of Appeal) and the Law Lords other than Lord Slynn in the combined appeal of Cockburn and Fairey (1997). This author believes that, perhaps consumed by elitist attitudes, many judges have been conspicuously reluctant to delve in the intricacies of Social Security Law properly where an engaging approach could lead to producing a fair enhancement in the benefits sought; see Ogus, Barendt \& Wikeley supra n.3 at p.687 \& Wikeley, supra n. 14 at p. 557. 41 Supra n.2 at 850 e.

${ }^{42}$ Hansard $7^{\text {th }}$ February, 1991 col.449. The current level of U.K. benefits is not sufficient to meet the care needs of a disabled person: see Horton and Berthoud, The Attendance Allowance and the Cost of Caring (London, P.S.I, 1990).
} 
of the cases of Mallinson (1994) and Fairey (1997), a blind person in August 2000 can be entitled to not more than $£ 49.45$ a week D.L.A. benefit (middle care and lower mobility components). Hardly a generous allowance having regard to the fact that according to an E.U. study a blind person requires $£ 238$ a week to cover the additional costs connected with his disability and the British Government pays $£ 335$ weekly Residential Care Allowance for caring for a severely disabled person in the Greater London area. If blindness occurs through an industrial accident then he/she is entitled to an Industrial Injuries Disablement Benefit of $£ 108.10$ weekly. In many European countries disabled persons are given as much as $£ 300$ weekly allowances to lead a normal life in society. The United Kingdom (which asserts to be a caring society and at present is one of the most successful economies in the world) can legitimately be expected to do better for its disabled population. Furthermore, about $£ 1.5$ billion each year remains unclaimed by those who are lawfully entitled to various benefits. This is mainly due to lack of information about the rules of entitlement, proud claimants refusing to claim because they feel that applying for social security benefits is not respectable, and general inefficiency in the D.S.S. system. ${ }^{43}$

However, society has not remained totally impervious to these concerns. The then Minister for Disabled People, Mr. Nicholas Scott, on $7^{\text {th }}$ February 1991 informed the House of Commons that the government expenditure on disability benefits over 1979-1991 had increased by 120 per cent.$^{44}$ Furthermore, $£ 1$ million a day was envisaged to be additionally spent on the enhancement of these benefits by the new legislation.

43 Indeed, the reform of the system has been called for over the previous years by many including its close scrutineers. Describing the process as "lamentable," Commissioner J. Mitchell in CA153-1989 said, "The sooner it is revised, the better." Michael Rowell, "Social Security Commissioners' Decisions" [1991] Journal of Social Welfare and Family Law 231 at pp. 237-238. The ordinary appellants find the detailed rules and procedures of Social Security Law "incomprehensible." Bell, "Social Security Tribunals, a General Prospective" (1982) 33 N.I.L.Q. 132 at p.141; see also K.Mullan, infra n.44 at p.69

${ }^{44}$ Hansard, supra n. 16. Highlighting some nonsensical distinctions drawn by other judges in reckoning the care needs of an incontinent claimant, Lord Slynn said, "It seems to me that the district nurse or healthcare worker ..... would be astonished that lawyers should draw such distinctions." (supra n.2 at 864). This comment may be justifiably attributed to the "restrictive" grant of benefits predicated by some judges which is contrary to the amplification of provision by Parliament. Thus Hansard can be referred to in aiding the statutory construction. The recent case law shows that courts are "liberal and permissive" to allow the adduction of Hansard in these circumstances where otherwise "absurdity" may ensue; see K. Mullan, "Pepper v. Hart and Social Security Law, Practice and Procedure" (1997) 4 J.S.S.L. No.2, 52 at p.70; also Bates, "The Contemporary Use of Legislative History in the United Kingdom" (1995) 54 C.L.J. 127. 
Contrasted with these facts, the courts' pre-occupation with safeguarding the public funds appears to be misconceived. Instead, it is not unfair to expect from the judiciary to seize upon the clear drifts in the mood of Parliament in a positive direction and take a pro-disabled approach where it is justified.

\section{HARSH WORKINGS OF THE DOCTRINE OF STARE DECISIS}

Substantial unfairness has been injected into the comprehension of relevant issues in this field by an over-technical and inflexible adherence by judges to the doctrine of stare decisis. In the Fairey case, Lord Justice Hobhouse, when justifying his view that "seeing" was not a "bodily function" and that Lord Woolf had got it wrong in the Mallinson case, buttressed it, inter alia, not only by referring to the 1984 judgment of the House of Lords, In Re Woodling (as if there is an absolute prohibition for a House of Lords bench sitting in 1994 not to depart from a decision taken in 1984), but also said that Lord Woolf's opinion was not in conformity with the Court of Appeal's decision in Packer's case of 1981 . $^{45}$

It appears that in the Mallinson case Lord Lloyd of Berwick could not fully appreciate the limitations imposed by the lack of eyesight, as compared with physical disabilities. His Lordship felt himself constrained by the syllogism that bodily functions were only those which "a fit man normally performs for himself. ${ }^{46}$ Accordingly, in the Mallinson case his Lordship could not treat "seeing" as a bodily function because it was not something a person "performed." Was it necessary for Lord Lloyd to adopt this approach?

The answer is "no." "Perform" or variations of this word do not feature in the parent legislation.

The idea that bodily functions have to be "performed" comes from a 1974 decision of a Social Security Commissioner. It was adopted by Lord Justice O'Connor in the Packer case in 1981 and then approved by Lord Bridge in the Woodling case in 1984. It is worth noting that neither the Commissioner nor subsequent court decisions categorised this definition of "bodily functions" so finely as to make any other definition impermissible. Without doing any violence to the statutory language whatsoever, one can safely say that bodily functions are those which a fit person performs for himself or would perform for himself but for the disability. Blindness is a disability and the person lacking the ability to see cannot perform many bodily functions. His care needs arising from his inability to perform such functions should correctly be held as giving

45 Supra n.2 at 865 .
46 Mallinson v. Secretary of State for Social Security [1994] I W.L.R. 630 at 659. 


\section{THE DENNING LAW JOURNAL}

him entitlement to a benefit which has been specifically provided by the Parliament for that purpose.

It is submitted that there is no restriction on judges to feel themselves imprisoned by words used in earlier decisions which are not in the parent statutory instruments. They should vigilantly ignore them in the cases where that is crucial to preserve the real spirit and "purpose" of the relevant legislation.

Relegating the animus legis to the second rank, and desisting from judicial intervention where thousands of disabled individuals were likely to be affected adversely if a positive, pro-active, justice-oriented intervention was not made, Lord Lloyd in the Mallinson case overly adhered to the "adversarial" tradition and said that since throughout the proceedings "walking" was the function on which the case of Mr. Mallinson was pleaded, he would not consider "seeing" to be the relevant function. ${ }^{47}$ Given the oft-acknowledged "inquisitorial" nature of the social security jurisdiction, this approach was wholly unjustified. On the other hand, acting as a judge in the "golden" tradition, Lord Woolf focussed his mind on "seeing" as being the function most relevant to dispose of the Mallinson case justly. A commentator categorised Lord Woolf"s approach as "imaginative" and "certainly more in keeping with the inquisitorial ethos of SSATs (Social Security Appeal Tribunals) and other tribunals" within the social security system. ${ }^{48}$

\section{THE FAIR APPROACH}

Lord Slynn's pronouncements in the Cockburn and Fairey judgments, it is submitted, reflect a thoroughly just and fair approach. His Lordship, whilst recognising the full extent of the lawful entitlement of disabled claimants and showing caring determination that they are not short-changed by the system, pays full regard to legal boundaries of the governing provisions. He mentions that the system is not "open-ended" and that:

"the question in each case is whether the particular activity said to be attention reasonably required by the individual because of the severe disability affecting the relevant function is reasonably required in connection with that function. ${ }^{349}$

Ibid.

${ }^{48}$ N. Wikeley, "Case Analysis - Mallinson" (1994) 1 J. of S.S. Law 80 at p.83

49 Supra n. 2 at 865. 


\section{DISABILITY BENEFITS LAW}

His Lordship spotlights the central purpose of the disability benefits as being devised to enable a disabled person to lead a normal life in a civic culture. He reiterates this theme in his dissenting judgment in the Cockburn case as follows:
"Thus, as I see it, the attention here is not to be seen as the act of taking a bundle of clothes to the laundry or to the laundrette, or putting them in the washing machine or wash them at home. The attention relied on is the act of making sure that the severely disabled person who cannot do these things for herself is kept clean and comfortable in decent conditions.

However, Lord Slynn also puts proper boundaries around what is acceptable to be taken into account in working out entitlement and states that "attention" "must have active, close caring personal qualities."

It is hoped that in future the judiciary takes as robust an attitude as Lord Slynn does. Given the professional circumspection with which his Lordship has expressed his views in the Cockburn and Fairey appeals, such an approach will be entirely just and fair.

\section{CONCLUSIONS}

After careful scrutiny of Packer's case (1981), the Woodling case (1984), the Court of Appeal decisions in the Mallinson, Fairey and Cockburn cases, and the opinions of the Law Lords in the cases of Mallinson (1994) and Fairey and Cockburn cases (1997), one finds that, even though not "compelled" by the parlance of the statute, the majority of judges have been restricting the availability of disability benefits, or the higher level of them, as follows:

(1) "Attention" required has been qualified not only to be of the "personal" or "close caring" variety but has to be "intimate" and rendered in the "presence" of the disabled person, or given in the course of the helper's "attendance on" him.

\footnotetext{
50 Ibid at 818-819. As compared with a "medical model," the "social model" of disability advocates the provision for catering "care needs" imposed on a person with disability for want of adequate services and the failure of the society to make appropriate adjustments to its infrastructure to meet the special requirements of a disabled person. I agree with Professor Wikeley when (categorising it as a "fundamental transformation") he says: "The decision in Fairey reflects a shift away from a purely medical model of disability" $\mathrm{N}$. Wikeley, supra n. 14 at p.560. For further details on this aspect, see two books by the leading proponent of the "social model" Professor. Mike Oliver, The Politics of Disablement (MacMillan, 1990) at p.32; and Understanding Disability: From Theory to Practice (MacMillan, 1996).

51 Supra $n .2$ at 865.
} 


\section{THE DENNING LAW JOURNAL}

The depth of detriment of this approach can be illustrated by the need of a blind person to read a letter. He has a fax machine and transmits it to somebody fifty miles away to read it to him over the telephone - not much different from the case of a physically disabled claimant who is incontinent and she cannot wash her clothes because of arthritis and her dirty bed linen and clothes are taken away by a carer to be cleaned at her own home where she wishes to do it because she has to supervise her young children at the same time. If current judicial approaches are faithfully applied, the care needs in the above two examples are not likely to be reckoned in working out the benefit entitlement.

(2) "Bodily functions" are construed with over-zealous regard for technicality. What are the exact care needs of disabled people, and which needs ought to be reasonably catered for, is lost sight of in the process.

(3) Either the judges themselves, or advocates presenting the cases before them, appear to be stuck in a time warp and judgments of 1981 and 1984 are being referred to as if there has been no appreciable shift in the provision of benefits by the Government, commensurately reflected in the more recent legislation.

(4) The judges, rather disappointingly, have failed in many cases to make a positive contribution to improving the plight of disabled people. They could at least refrain from interpreting the relevant statutes negatively. In this regard the disabled claimants and pursuers of their fair claims, however, cannot overlook the constructive contribution of some judges who have interpreted the law fairly and in line with the changing social policy, particularly, Lord Woolf in the Mallinson case and Lord Slynn in the Cockburn and Fairey cases. More of this kind of fair and balanced approach is needed to be taken by judges dealing with cases in this field, always wary of the fact that, hopefully with more willingness of the society and Parliament to make better provision for disabled citizens, the earlier precedents will become even more irrelevant and discardable. 